\title{
Ultrastructure of the Intermediate Stages in the Reverting L-phase Organisms of Staphylococcus aureus and Streptococcus faecalis
}

\author{
By J. K. SCHÖNFELD \\ Bacteriological Laboratory of the Rotterdam Municipal Hospitals, P.O. Box 1738, Rotterdam \\ AND W. C. DE BRUIJN \\ Laboratory for Electron Microscopy (Pathological Laboratory I), \\ Erasmus Univérsiteit, Rotterdam, The Netherlands
}

(Received 2 October 1972 ; revised 6 March 1973)

\begin{abstract}
SUMMARY
The structure of several developmental stages of the reverting L-phase organisms of Staphylococcus aureus and Streptococcus faecalis are shown. Electron-dense spherules were observed inside the reverting organisms. These spherules could separate from the main organism and develop into walled cocci.
\end{abstract}

\section{INTRODUCTION}

In our previous publications the morphology of Staphylococcus during its transformation into the L phase was studied (Schönfeld, 196I). Changes took place within Io h after inoculation on hypertonic media containing penicillin. No intermediate stages between $\mathrm{B}$ (acterial) and $\mathrm{L}$ phase were observed. Presumptive evidence was obtained that $\mathrm{L}$ organisms are more than 'bacteria which synthesize a defective wall' (Stanier, Doudoroff \& Adelberg, I965), but the essential process remained obscure. Subsequently a phase-contrast study (Schönfeld, I963) suggested that during reversion ( $\mathrm{L} \rightarrow$ Staphylococcus) intermediate stages were present. In the present electron-microscopic study we have made a search for such stages. For comparison, Streptococcus faecalis was studied as well.

\section{METHODS}

Staphylococcus aureus 10033 and Streptococcus faecalis 962 were hospital isolations. Staphylococci were made resistant to neomycin, I00 $\mu \mathrm{g} / \mathrm{ml}$.

The L phase was induced by inoculation on solid medium (Schönfeld, I96I) supplemented with $\mathrm{I} 00 \mathrm{u}$ of penicillin $\mathrm{G} / \mathrm{ml}$. To bring about reversion $\mathrm{I} \mathrm{cm}^{2}$ agar blocks were cut from the penicillin-containing medium bearing $\mathrm{L}$ colonies grown overnight, and were then put face downwards on a medium without penicillin. A dose of commercial penicillinase, which according to the producer (Mycopharm, Delft, The Netherlands) could inactivate $200000 \mathrm{u}$ of penicillin, was applied on top of the block. After I5, 20 and $30 \mathrm{~h}$ small agar columns were cut through both layers and the colonies were fixed in situ as described below. The rest of the medium was reincubated to check reversion. In order to make suspensions necessary for culture in liquid medium, blocks containing the colonies were triturated in a wide test tube, a small one being used as a pestle. The liquid medium contained the same constituents as the solid one except agar. 


\section{Electron microscopy}

The agar columns were fixed in $3 \%$ glutaraldehyde in 0.1 M-sodium cacodylate buffer containing $0.05 \mathrm{M}$-calcium chloride ( $\mathrm{pH} \mathrm{6.0)}$ ) at $4{ }^{\circ} \mathrm{C}$ for $24 \mathrm{~h}$. Subsequently the material was rinsed in the same buffer and stored in that buffer without glutaraldehyde for at least $24 \mathrm{~h}$ at $4{ }^{\circ} \mathrm{C}$. Before use it was rinsed in double-distilled water, incubated at $22{ }^{\circ} \mathrm{C}$ in Michaelis buffer ( $\mathrm{pH}$ 6) for $\mathrm{I} \mathrm{h}$ and post-fixed in a $\mathrm{I} \%(\mathrm{w} / \mathrm{v})$ osmium tetroxide solution in the same buffer to which was added $0 . \mathrm{I} \%$ tryptone and $0 . \mathrm{I} \%$ (w/v) $\mathrm{CaCl}_{2}$ at $4{ }^{\circ} \mathrm{C}$ for $\mathrm{I} 8$ to $24 \mathrm{~h}$. After rinsing in Michaelis buffer the columns were kept for $2 \mathrm{~h}$ at $22^{\circ} \mathrm{C}$ in $0.0 \mathrm{I} \mathrm{M}-$ uranyl acetate in Michaelis buffer (Kellenberger \& Ryter, 1964). The material was then rinsed in double-distilled water, dehydrated in increasing concentrations of acetone, impregnated in an acetone-Epon $\mathrm{C}$ mixture $\mathrm{I}: \mathrm{I}$ and embedded in fresh Epon $\mathrm{C}$, which was polymerized for $72 \mathrm{~h}$ at $37^{\circ} \mathrm{C}$. For further details see de Bruijn (I969).

A second stain, lead citrate (Venable \& Coggeshall, 1965), was occasionally used.

\section{RESULTS AND DISCUSSION}

Previous investigations (Schönfeld, I96I) established that a proportion of the Staphylococcus $L$ organisms remain unstable even after 200 passages in the $L$ phase. Attempts to get reversion of all the colonies by changing the growth conditions of the $\mathrm{L}$ organisms were unsuccessful. However, the reversion rate was increased by making the original Staphylococcus strain resistant to tyrothricin or neomycin before its transformation into the $\mathrm{L}$ phase. This method had been used before (Schönfeld, 1959) to obtain marked organisms. During the present investigation it became clear that these resistant organisms reverted more easily than the original strains. Reversion of relatively stable L forms (McGee, I97I) was made possible after making a suspension of the colonies of the $200+n^{\text {th }}$ passage, shaking it in liquid medium, and plating it out after $24 \mathrm{~h}$ on solid medium. In reverting L-phase organisms which had had many passages in the L phase the intermediate stages were slightly longer than in relatively new L-phase organisms. This gave the opportunity to observe the metamorphosis during a prolonged interval.

Most of the $\mathrm{L}$ colonies eventually reverted after the penicillin was removed from the medium, but at any given moment only a small number of the organisms within the colony were reverting, the others remaining static. Synchronization of the metamorphosis was never obtained, various stages of reversion being found simultaneously.

Differences were observed between the reversibility of Staphylococcus aureus and Streptococcus faecalis $\mathrm{L}$ organisms.

(i) Reversion of Staphylococcus aureus was still possible after 280 passages in the $\mathbf{L}$ phase, but Streptococcus faecalis ceased to revert to the bacterial phase after only 30 passages in the L phase. In our experiments we used an 8th passage of Streptococcus faecalis L-phase organisms.

(ii) In contrast to the results with Staphylococcus aureus the reversion rate of the Streptococcus faecalis $\mathrm{L}$ organisms could not be increased either by making the original bacteria resistant to neomycin or tyrothricin or by shaking a suspension of $\mathrm{L}$ organisms in liquid medium.

(iii) The first fully reverted staphylococci in the reverting colonies were found about $20 \mathrm{~h}$ after penicillinase was added. Completely reverted streptococci were not found until at least $30 \mathrm{~h}$ after penicillinase was added. 


\section{Morphology}

L-phase organisms. In both species the nuclear material was visible as a highly diffused network of thin threads, whereas the cytoplasm appeared to be coarsely granular material. All organisms were enclosed in a unit membrane (Fig. I, 9). Neither walls nor wall-remnants were observed. These extremely pleomorphic organisms were several times larger than cocci.

L organisms of staphylococci were more convoluted and had more foci or nuclear material than L organisms of Streptococcus faecalis. In the L-phase organisms of Staphylococcus aureus 10033 , crystalline lattice (Fig. 6) structures were regularly seen in the cytoplasm. These structures were not observed in Streptococcus faecalis nor in other Staphylococcus strains.

Lattice structures in Clostridium cochlearium have been described by Pope, Yolton \& Rodes (I968) and in Bacillus thuringiensis by Norris \& Proctor (I969). Both groups of authors considered them to be connected with phage production.

Bacteria. Cells were oval to round. The wall appeared as a thick electron-dense layer outside the cytoplasmic membrane (Fig. 2, I0). The ribosomal particles were smaller and more closely packed in the cocci than in the L-phase organisms. Mesosomes were regularly found to accompany the developing walls, but are not illustrated here.

Intermediate stages. When penicillinase was added to the medium many organisms in the colonies gradually became modified: the cytoplasm became denser, and the nucleus shrank, becoming round or oval, its internal structure becoming distinctly thread-like. In some of the modified $\mathrm{L}$ organisms electron-dense spherules developed (Fig. 3, 4, 5, 6, 7, II, I2). No unit membrane was apparent around these spherules but at certain places indistinct membranes appeared on their periphery (Fig. 7). In some of the main organisms the boundary membrane to the outside of the spherule was missing (Fig. 8). In other sections the spherules were seen at some distance from the main body (Fig. 13) which suggested that the spherules could separate from the main body.

The free organisms gradually changed into cocci. In Fig. I4 the central electron-dense part shows similarity to the spherules, whereas the peripheral parts are gradually changing into cocci. The walls are not yet completely developed.

The morphology of the intermediate stage of development was slightly different in the two strains investigated. In the Staphylococcus $L$ organism invagination of nuclear and cytoplasmic material took place. A spherule was formed which was surrounded by an electron-transparent zone. In the Streptococcus faecalis $\mathbf{L}$ organisms the electron-dense material also accumulated eccentrically. No electron-transparent halo was found, but a protuberance was formed.

Electron-dense bodies in cocci have been described by Rimkunas \& Chumachenko (1971) and Corfield \& Smith (1970). Neither of these groups saw them split off nor did they consider them to be intermediary stage organisms.

We observed these spherules regularly in reverting L-phase organisms of both Staphylococcus aureus and Streptococcus faecalis but not in established L-phase organisms nor in the coccus. They develop from a small part of nuclear and cytoplasmic material (Fig. 3). Neither regular cell divisions giving rise to monomorph coccoid organisms nor walls developing around L-phase organisms were ever observed. In our opinion these spherules must be considered to be an intermediate stage in the reversion.

Wall formation was sometimes not completed before a few divisions in the bacterial phase took place. 

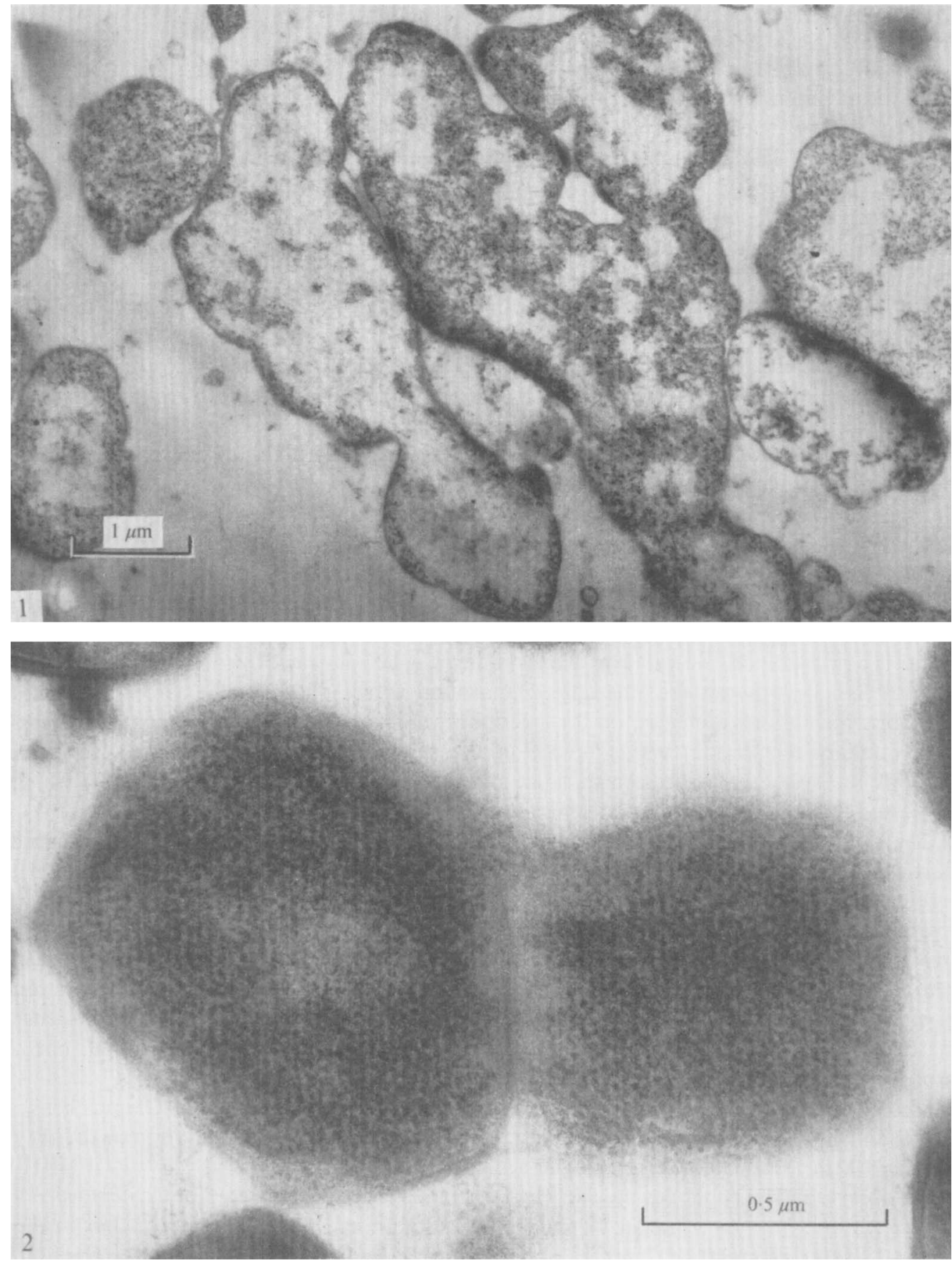

Fig. I. L-phase organisms of Staphylococcus aureus 10033N after I84th passage on penicillincontaining medium. Nuclear and cytoplasmic material intermingled. Counterstained with lead citrate.

Fig. 2. Bacterial-phase Staphylococcus aureus I0033N, from I6oth passage L phase after $24 \mathrm{~h}$ reversion on solid medium. Counterstained with lead citrate. 

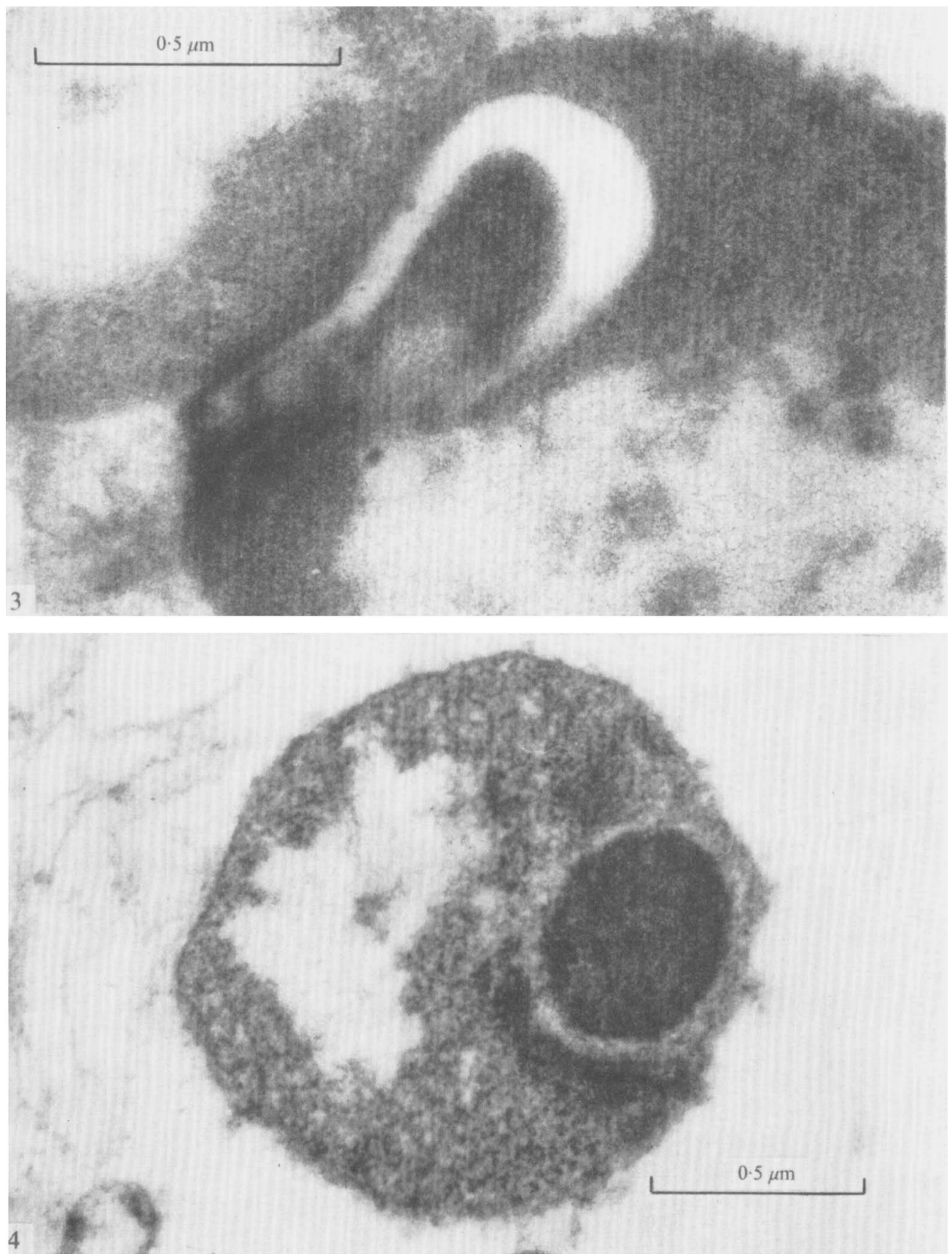

Fig. 3-7. Staphylococcus aureus $10033 \mathrm{~N}$ after 280 th passage in L phase. Reversion partly in liquid, partly on solid medium.

Fig. 3. Developing inclusion body.

Fig. 4. Inclusion body in electron-transparent 'halo'. 

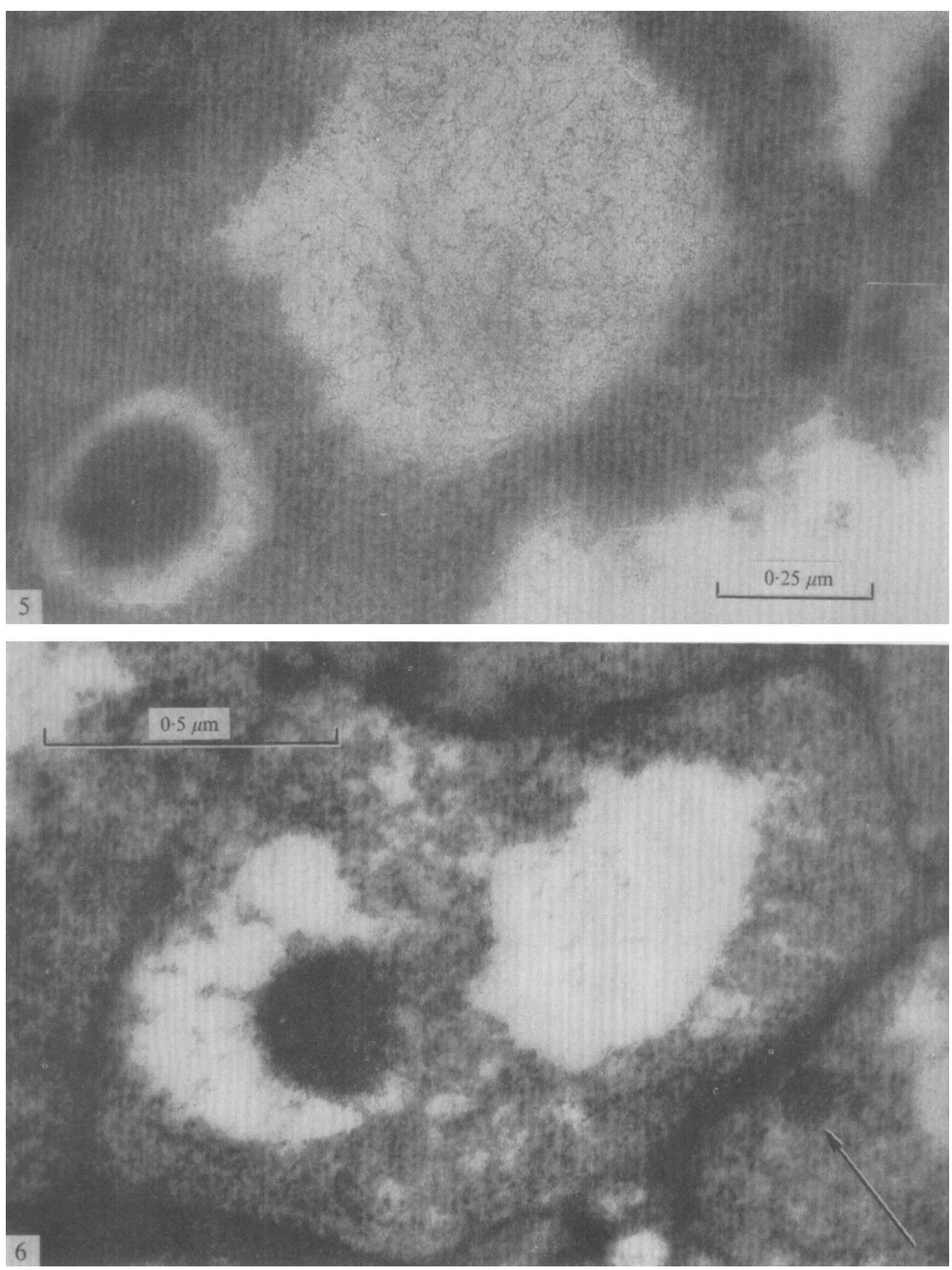

Fig. 5. Inclusion body in electron-transparent 'halo'.

Fig. 6. Inclusion body and phage lattice (arrow). 

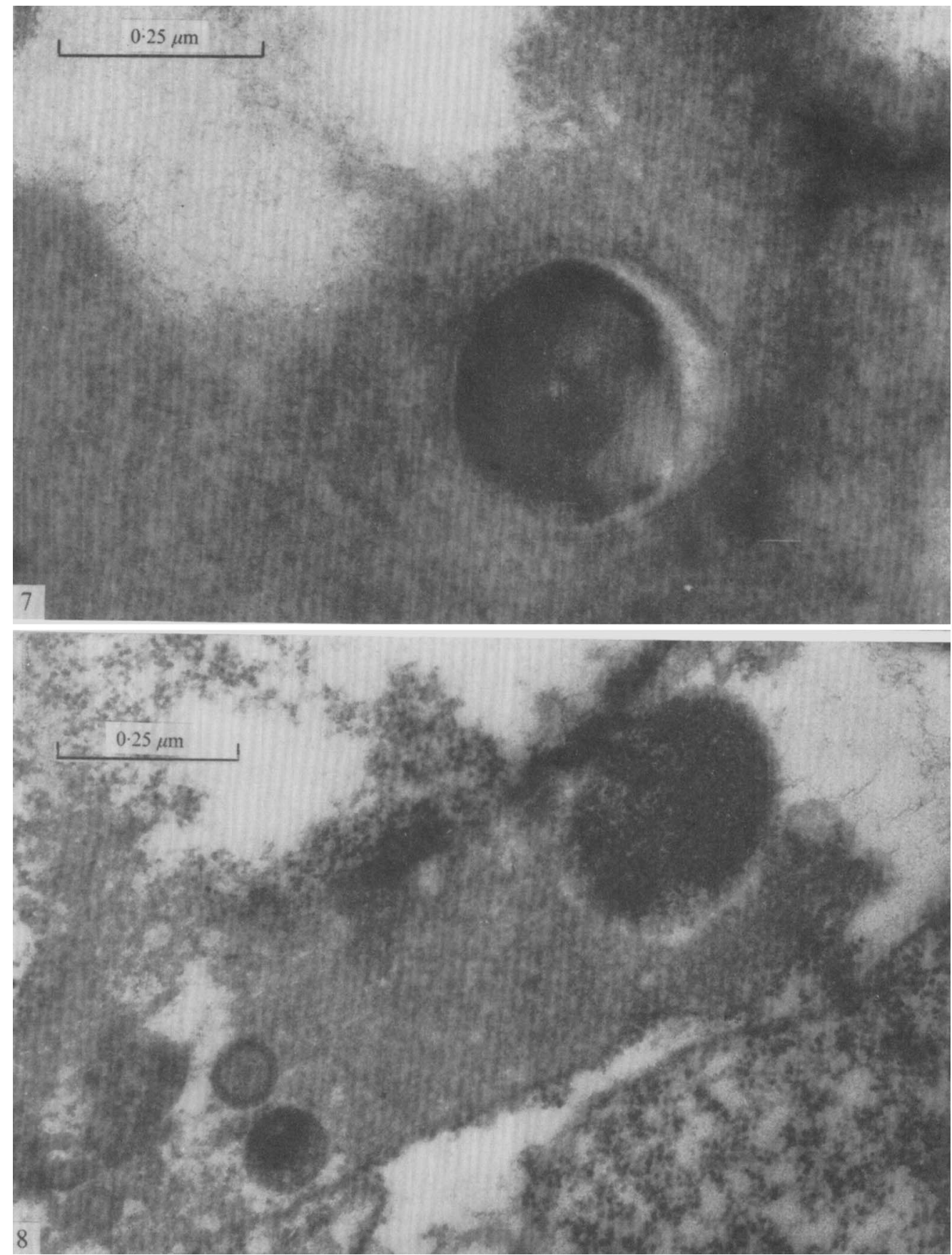

Fig. 7. Inclusion body with indistinct peripheral membrane.

Fig. 8. Staphylococcus aureus I0033N. Reversion partly in liquid, partly on solid medium. Inclusion body in open socket. 

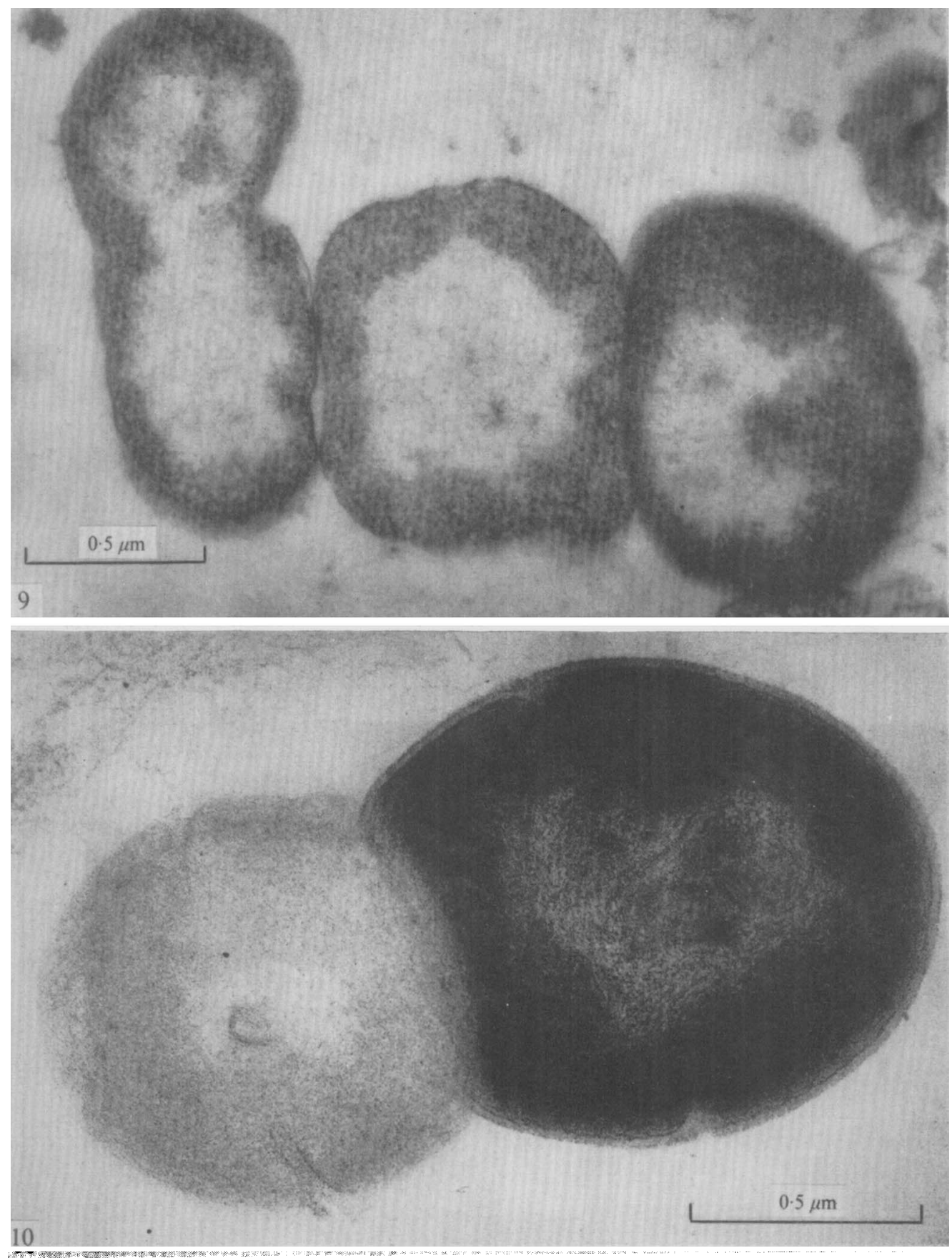

Fig. 9. Streptococcus faecalis $962,84^{\text {th }}$ passage in $\mathrm{L}$ phase on penicillin-containing medium.

Fig. 10. Streptococcus faecalis 962 . Developing coccus, $40 \mathrm{~h}$ reversion. 

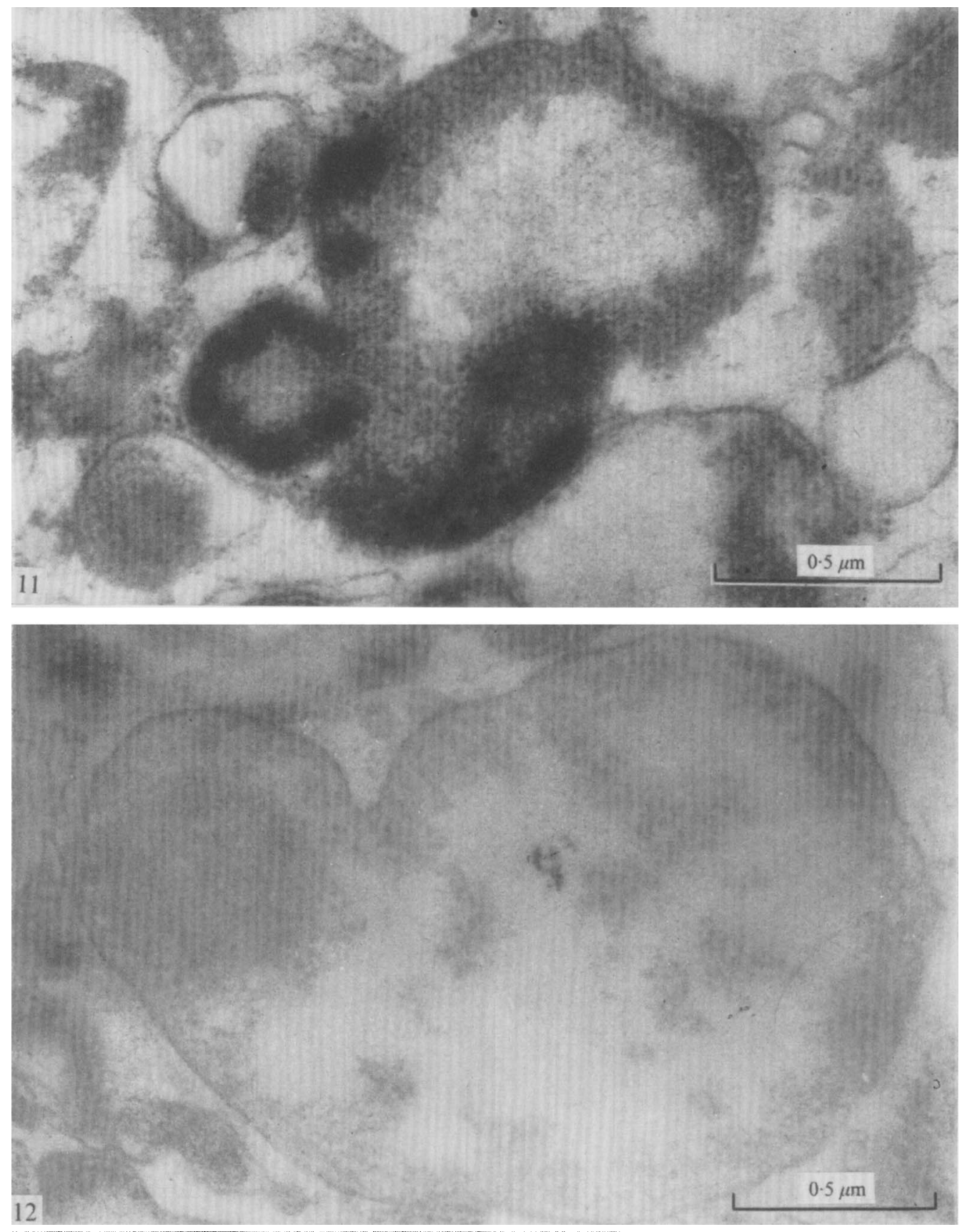

Fig. I1, I2. Streptococcus faecalis 962,8 th passage in L phase. Reversion during $40 \mathrm{~h}$. Peripheral constriction with inclusion body. No electron transparent 'halo'. 

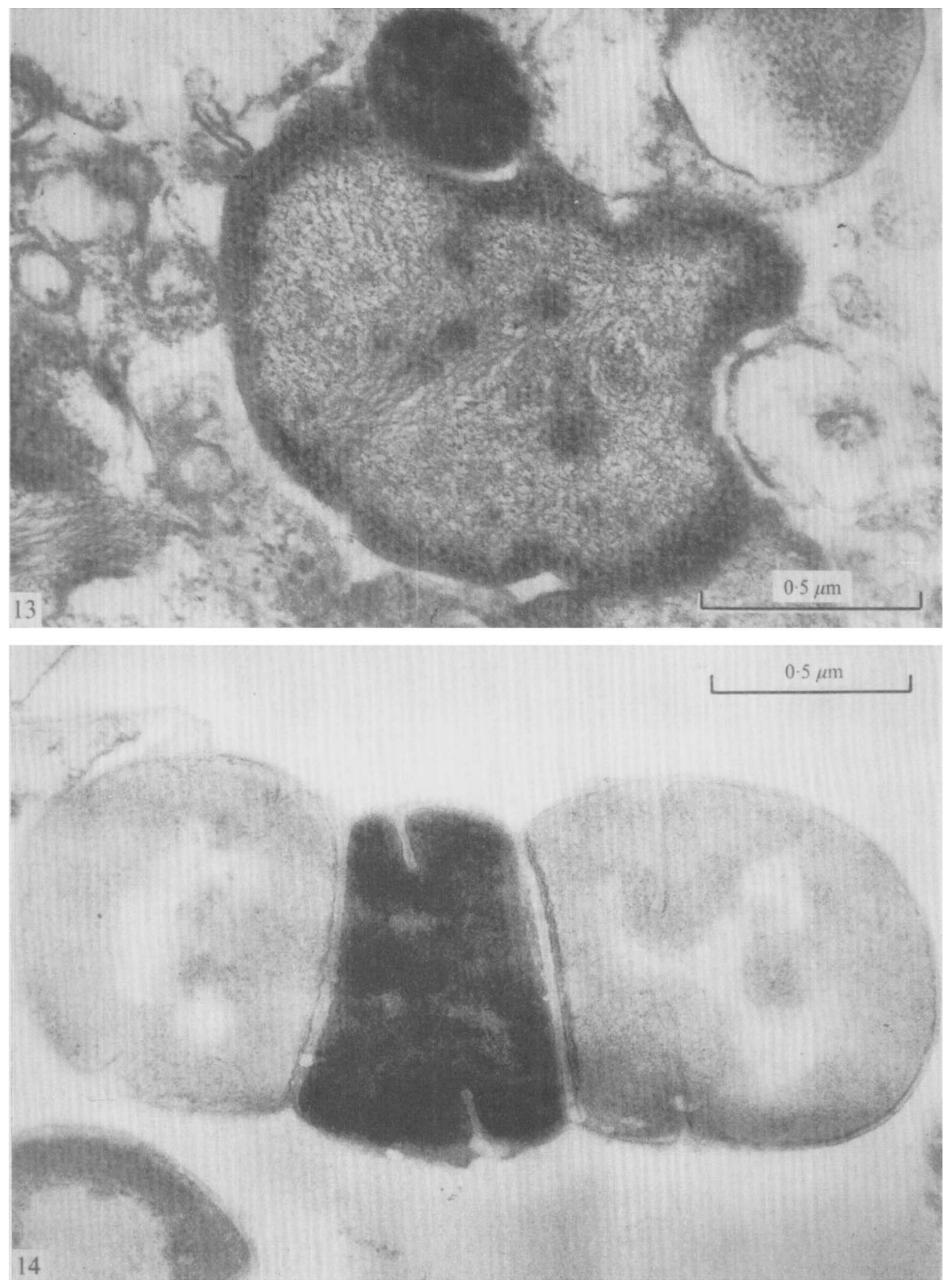

Fig. 13. Streptococcus faecalis 962 . Inclusion body separated from main organism.

Fig. I4. Streptococcus faecalis 962 developing cocci with deficient walls. The wall in its stage of development may be compared with the wall of the coccus in the lower left corner. 
We thank Mrs J. Overbeek-Hensen (bacteriology) and Mrs W. van Harstkamp-Roodbeen (photography) for their excellent technical assistance.

\section{REFERENCES}

DE BRUIJ, W. C. (1969). De pathogenese van experimenteel verwekte atheromatose bij konijnen. Thesis, University of Leiden.

CORFIELD, P. S. \& SMITH, D. C. (I970). Ultrastructural changes during propagation of a group D streptococcal L-form. Archiv für Mikrobiologie 75, I-9.

Kellenberger, E. \& Ryter, A. (I964). In Modern developments in electron microscopy, p. 364. Edited by B. M. Siegel. New York and London: Academic Press.

MCGeE, Z. A. (197I). Wall defective microbial variants. Journal of Infectious Diseases 123, 433-438.

Norris, J. R. \& Proctor, H. M. (1969). Crystalline inclusions in Bacillus thuringiensis. Journal of Bacterio$\log y 98,824-826$.

Pope, L., Yolton, D. P. \& Rodes, L. J. (1968). Crystalline inclusions in Clostridium cochlearium. Journal of Bacteriology 96, 1859-1862.

Rimkunas, A. \& CHUMACHENKo, N. V. (I971). Ultrastructure of the streptococcus in different stages of the $\mathrm{L}$ transformation (in Russian). Zhurnal Mikrobiologii, Epidemiologii i Immunobiologii 4, 64-68.

SCHÖNFELD, J. K. (1961). L forms of Staphylococcus. Studies on the morphology of the transformation and on the reversibility. Antonie van Leeuwenhoek 27, I39-150.

SChÖNFELD, J. K. (1963). Pleiomorphe tussenstadia in de 'L' cyclus van Staphylococcus. Acta Leidensia 32, 259-262.

Stanier, R. Y., Doudoroff, N. \& Adelberg, E. A. (1965). In The Microbial World, p. 186. Englewood Cliffs: Prentice Hall.

Venable, J. H. \& Coggeshall, R. (1965). A simplified lead citrate stain for use in electron microscopy. Journal of Cell Biology 25, 407. 